The University Language/Learning Laboratory

A Survey of the Facilities:

Their Technologies; Disciplines; Organizations

Rhoda Stern, Baruch College, CUNY

Editor's Note: This is the first of a two-part study conducted by Ms. Stern. The second part will be published in the next issue of the Journal.

This study examines language and learning laboratories as they exist today in colleges and universities across the United States. It is the result of 89 responses to a questionnaire sent to 150 institutions. The type of facility, the technologies available, the disciplines served and the organizational structures established are examined individually and in their relationships to each other in the following order: 1) the nature of the facility; 2) the person in charge; 3 ) the person reported to; 4) others employed in the facility.

\title{
The Nature of The Facility
}

The Facility

The participating schools were selected from the New York metropolitan area and from the membership directory of the NALLD Journal. All but seven, community colleges comprising the City University of New York complex, are four-year institutions. The laboratories polled are categorized under four major identifications: 1. Language Laboratories; 2. Language Centers; 3. Learning Laboratories/Centers; 4. Other Names, i.e. Listening Labs, Autotutorial Labs, etc. The overwhelming majority of the labs, 79.8 percent, are known as language laboratories: 


\section{The Facility}

Table 1

Name of Facility

1. Language Laboratory(ies)

Language Media Laboratory Modern Language Laboratory(ies)

Foreign Language Laboratory (ies)

2. Language Center(s)

Language Learning Center

Language Learning Technology
Number of Percentage of Labs Total Responses

$79.8 \%$

1

3

8

3. Individualized/Electronic

Learning Labs

Learning Lab Center

Learning Center(s)

Learning Resource Center

4. Media Center

Sound Lab

Viewing and Listening Lab

Listening Center

Autotutorial Lab

Multi-Media Tutorial
2

1

1
$4.5 \%$

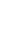


The Technologies Available

Table 2

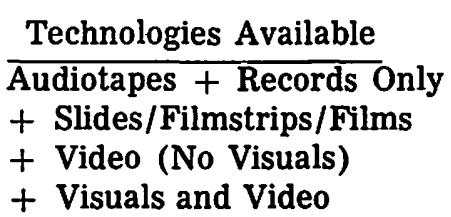

\begin{tabular}{ccc}
$\begin{array}{c}\text { Number of } \\
\text { Labs }\end{array}$ & $\begin{array}{c}\text { Percentage of } \\
\text { Total Responses }\end{array}$ \\
\cline { 1 - 1 } $\begin{array}{c}58.9 \% \\
12\end{array}$ & & $13.5 \%$ \\
14 & & $15.7 \%$ \\
15 & & $16.9 \%$
\end{tabular}

The extent to which these audio and visual technologies are implemented was not determined by this survey.

\section{The Disciplines Served}

There are three major types of labs based upon the number of disciplines available within each: those that serve 1) only the foreign languages; 2) the foreign languages including English as a Second Language; 3 ) the foreign languages, ESOL and three or more additional disciplines ranging from the related areas of Speech, Communications, Linguistics and Music to Math, Biology, Psychology, Education, Engineering, etc. The greatest number of labs exist to accommodate only foreign languages, followed by labs which serve numerous disciplines. The last large grouping of labs serves the foreign languages and English as a Second Language.

The Disciplines Served

Table 3

\begin{tabular}{lrrr}
\multicolumn{1}{c}{ Disciplines Served } & $\begin{array}{c}\text { Number of } \\
\text { Labs }\end{array}$ & $\begin{array}{c}\text { Percentage of } \\
\text { Total Responses }\end{array}$ \\
Foreign Languages Only & 33 & & $37.1 \%$ \\
FL + 1 or 2 Additional Disciplines & & & $4.5 \%$ \\
FL/ESOL Only & 17 & & $19.1 \%$ \\
FL/ESOL + 1 or 2 Addit'l Disciplines & 7 & & $7.9 \%$ \\
FL/ESOL + 3 or More Disciplines & 22 & & $24.7 \%$ \\
English/ESOL Only & 2 & & 2.25 \\
ESOL + or More Disciplines & & 2 & 2.25 \\
Other (Biology) & 1 & \\
Unknown & 1 &
\end{tabular}

As with technologies available, the extent to which each discipline is served was not determined by this survey. 


\section{University Laboratory}

\section{Distribution of Technologies over Disciplines}

When only the foreign languages and/or ESOL are represented in a facility, audiotapes and records are the only technologies in use in $\mathbf{3 3 . 8}$ percent of the participating labs. Although visuals are used slightly less than video across all labs, 13.5 percent vs. 15.7 percent, in those labs which serve only the foreign languages, visuals are used slightly more, 7.9 percent vs. 6.7 percent. Together, visuals and video appear to have made little entry into the foreign language/ESOL arena. Of the labs serving these disciplines alone, only 2.2 percent offer both technologies. Visuals and video together are implemented more frequently in labs offering numerous disciplines: 12.4 percent of the response.

Distribution of Technologies over Disciplnes Table 4

\begin{tabular}{lcccc}
\cline { 2 - 5 } & \multicolumn{3}{c}{ Technologies } & \\
& Tapes/Records & & +Video \\
& Only & +Visuals & +Video & +Visuals \\
\hline Foreign Languages Only & $21.4 \%$ & $7.9 \%$ & $6.7 \%$ & $1.1 \%$ \\
FL + 1 - 2 Disciplines & 2.25 & $1.1 \%$ & $\ldots$ & $1.1 \%$ \\
FL/ESOL Only & $12.4 \%$ & 2.25 & $3.4 \%$ & $1.1 \%$ \\
FL/ESOL + 1-2 Disciplines & $5.6 \%$ & $\ldots$ & 2.25 & $\ldots$ \\
FL/ESOL + 3 or More Disciplines & $9.0 \%$ & 2.25 & $3.4 \%$ & $10.1 \%$ \\
English/ESOL Only & 2.25 & $\ldots$ & $\ldots$ & $\ldots$ \\
ESOL + 3 or More Disciplines & $\ldots$ & $\ldots$ & $\ldots$ & 2.25 \\
Other (Biology) & $\ldots .$. & $\ldots$ & $\ldots$ & $1.1 \%$ \\
Unknown & $1.1 \%$ & $\ldots$ & $\ldots$ & $\ldots$
\end{tabular}

(The Distributions of Disciplines and Technologies over Facilities are found in Appendix A, Tables A-1 and A-2).

\section{Student Positions}

Student positions range from 16 to 524 in from 1 to 63 rooms. The greatest number of labs, 21.4 percent, report serving 30 to 38 students in one room. The next most frequent response, 14.6 percent, reports 60 to 70 positions in two rooms. This is followed by 13.5 percent of the total response reporting 40 to 53 positions in one room. Rooms used for recording, duplicating, storage, office, et.al. are not included in the table below. The columns represent the number of labs by rooms and student positions. 
University Laboratory

Student Positions

Table 5

Number of

Total Number

Positions

of Labs

\begin{tabular}{|c|c|c|c|c|c|c|c|c|c|c|c|}
\hline & & & $\overline{u m}$ & $\overline{\mathrm{er}}$ & Ro & $\overline{\mathrm{ms}}$ & with & Posi & tion & & \\
\hline & 1 & 2 & 3 & 4 & 5 & 6 & 10 & 20 & 63 & $?$ & \\
\hline $16-28$ & 6 & 3 & & & & & & & & & 9 \\
\hline $30-38$ & 119 & & & & & & & & & & 19 \\
\hline $40-53$ & 12 & 2 & & & & & & & & & 14 \\
\hline $60-70$ & 4 & 13 & & & & & & & 1 & & 18 \\
\hline $72-80$ & 3 & 1 & & & & & & & & & 4 \\
\hline $95-106$ & 1 & 3 & 5 & & & & & & & & 9 \\
\hline$\overline{119-128}$ & & 1 & 2 & 1 & & & & & & 1 & 5 \\
\hline$\overline{150-151}$ & & & & & 2 & & & & & & 2 \\
\hline 182 & & & & & & 1 & & & & & 1 \\
\hline$\overline{234-240}$ & 1 & & & & 1 & 1 & & & & & 3 \\
\hline$\overline{300}$ & & & & & & & 1 & & & & 1 \\
\hline 524 & & & & & & & & 1 & & & 1 \\
\hline Unknown & & 2 & & & & & & & & 1 & 3 \\
\hline
\end{tabular}

Five of the six labs in Group 4, Other Names, contain the smallest number of student positions. The sixth contains the greatest number of positions. Laboratories identified as language labs et.al., Group 1, most frequently hold $60-70$ booths and $30-38$ booths followed by $40-53$ booths Also, the larger the facility, the more frequently the utilization of video.

The Organization of the Facility

The Person in Charge: Title

Laboratory leadership is primarily male: 70.6 percent of those in charge are men, 27.2 percent women. Some 58.7 percent of the total responses bear the title Director: 66.2 percent of all men and 44 percent of all women. Men do not use or are not assigned any other title as frequently as this one while 28 percent of the women are also referred to as Supervisor. Three cf the laboratories report dual leadership accounting for the total of $\mathbf{9 2}$ below. 
The Person in Charge: Title

Table 6

\begin{tabular}{|c|c|c|c|c|}
\hline \multirow[b]{2}{*}{ Title In Charge } & \multirow[b]{2}{*}{$\mathbf{M}$} & \multicolumn{2}{|c|}{$\overline{ }$} & \multirow[b]{2}{*}{$\begin{array}{l}\text { Percentage of } \\
\text { Total Responses }\end{array}$} \\
\hline & & $\mathbf{F}$ & Total & \\
\hline Director & 43 & 11 & 54 & $58.7 \%$ \\
\hline Coordinator & 3 & 1 & 4 & $4.3 \%$ \\
\hline Supervisor & 2 & 7 & 9 & $9.8 \%$ \\
\hline \multicolumn{5}{|l|}{ Other } \\
\hline Administrator/Manager & 1 & 2 & 3 & $14.1 \%$ \\
\hline Technician & 3 & $\mathbf{0}$ & 3 & \\
\hline Instructional Aide & $\mathbf{0}$ & 1 & 1 & \\
\hline Assistant-Hourly & 1 & 1 & 2 & \\
\hline Research Assistant & 1 & $\mathbf{0}$ & 1 & \\
\hline Chairman & 2 & 0 & 2 & \\
\hline $\begin{array}{c}\text { Head of Undergraduate } \\
\text { Language Program }\end{array}$ & \multicolumn{4}{|c|}{ Language Program } \\
\hline No Title & 2 & $\mathbf{0}$ & 2 & $2.2 \%$ \\
\hline Title Unknown & 6 & 2 & 8 & $8.7 \%$ \\
\hline No one person in charge & & & 2 & $2.2 \%$ \\
\hline & 0 & $\overline{25}$ & 92 & \\
\hline
\end{tabular}

The Person in Charge: Rank

Academic appointments are held by 50 percent of those affiliated with the laboratories while 34.5 percent are administrative appointments. Men appear to be concentrated at the associate and assistant professorial rank followed by middle/low level administrative appointments. ${ }^{1}$ These three categories total 52.3 percent of all male appointments. Women are concentrated at the middle/low administrative level, the instructor/lecturer rank and the City University of New York College Laboratory Technician line. ${ }^{2}$ These three constitute 76 percent of all female appointments.

iMiddle/low and high managerial are defined in terms of salary. Administrative appointments earning above $\$ 18,500$ are considered high managerial in this report. All other administrative persons are middle/ low level managers. 
The Person in Charge: Rank

Table 7

\begin{tabular}{|c|c|c|c|c|}
\hline \multirow[b]{2}{*}{ Rank in Charge } & \multirow[b]{2}{*}{$\mathbf{M}$} & \multirow[b]{2}{*}{$\mathbf{F}$} & \multirow[b]{2}{*}{ Total } & \multirow[b]{2}{*}{$\begin{array}{l}\text { Total Responses } \\
\text { Total Rtsponses }\end{array}$} \\
\hline & & & & \\
\hline $\begin{array}{l}\text { Academic Appointment } \\
\text { Professor } \\
\text { Associate Professor } \\
\text { Assistant Professor } \\
\text { Instructor/Lecturer }\end{array}$ & $\begin{array}{r}6 \\
12 \\
12 \\
6\end{array}$ & $\begin{array}{l}0 \\
1 \\
3 \\
6\end{array}$ & $\begin{array}{r}6 \\
13 \\
15 \\
12\end{array}$ & $\begin{array}{r}6.5 \% \\
14.1 \% \\
16.3 \% \\
13.0 \%\end{array}$ \\
\hline $\begin{array}{l}\text { Academic/Administrative } \\
\text { College Lab Technician }\end{array}$ & 4 & 5 & 9 & $9.8 \%$ \\
\hline $\begin{array}{l}\text { Administrative Appointmen } \\
\text { High Managerial } \\
\text { Middle/Low Managerial } \\
\text { Technician }\end{array}$ & $\begin{array}{l}3 \\
9 \\
3\end{array}$ & $\begin{array}{l}0 \\
8 \\
0\end{array}$ & $\begin{array}{r}3 \\
17 \\
3\end{array}$ & $\begin{array}{r}3.3 \% \\
18.4 \% \\
3.3 \%\end{array}$ \\
\hline $\begin{array}{l}\text { Other Appointments } \\
\text { Research Assistant } \\
\text { Undergrad/Grad Asst. } \\
\text { Hourly Assistant } \\
\text { Rank Unknown } \\
\text { Not Applicable }\end{array}$ & $\begin{array}{l}1 \\
1 \\
1 \\
7\end{array}$ & $\begin{array}{l}0 \\
1 \\
1 \\
0\end{array}$ & $\begin{array}{l}1 \\
2 \\
2 \\
7 \\
2\end{array}$ & $\begin{array}{l}1.1 \% \\
2.2 \% \\
2.2 \% \\
7.6 \% \\
2.2 \%\end{array}$ \\
\hline
\end{tabular}

Of those in charge of the laboratories, 21.7 percent have other responsibilities: three are Chairmen and seventeen teach. Four of the seventeen report a full course load; three a three-credit reduction in their teaching responsibilities and two a one-half teaching load.

2The City University of New York College Laboratory Technician is on the Instructional Staff following administrative guidelines. In this report, the line is classified as middle/low managerial and is included in the administrative percentage, 34.5 percent.

The extent of the laboratory commitment i.e. full-or part-time appointment, is not made clear for 37 perrent of the leadership. Also, the number of full-time administrative appointments in academic lines is not determined. When the total leadership is considered over laboratories, the following figures emerge: 82.4 percent of those teaching are affiliated with language laboratories; learning labs are staffed by more full-time appointments than any other type of lab in proportion to their number . . 75 percent of their readership is a full-time appointment compared with 29.7 percent of the language laboratory leadership. 
Distribution of Title over Rank

The title, Director, is reported to be utilized by 71.7 percent of those in academic appointments. The only other title given by those in the assistant, associate or professorial rank is Chairman or Head. (Conversely, 61.1 percent of all Directors are in academic appointments.) The City University College Lab Technicians and female administrative appointments tend to bear titles other than Director. Only 33.3 percent of the Lab Technicians utilize the title Director while 55.6 percent utilize the title Supervisor, Coordinator or Technician. Of the women in administrative appointments, $\mathbf{7 5}$ percent are known as Supervisor, Manager or Administrative Assistant.

\begin{tabular}{|c|c|c|c|c|c|c|c|c|c|c|}
\hline \multirow[b]{2}{*}{ Rank } & \multirow[b]{2}{*}{ Dir. } & \multicolumn{6}{|c|}{$\frac{\text { Disstribution of Title over Rank }}{\text { Table } 8}$} & \multirow[b]{2}{*}{$\begin{array}{l}\text { No } \\
\text { Title }\end{array}$} & \multirow{2}{*}{\multicolumn{2}{|c|}{$\begin{array}{l}\text { Title } \\
\text { Unknown }\end{array}$}} \\
\hline & & Coord. & Supvsr. & Mgr. & Tech. & Chrmn. & Other & & & \\
\hline & MF & $\mathbf{M F}$ & MF & M F & M F & M F & M F & M F & & $\mathbf{F}$ \\
\hline Professor & 3 & & & & & 2 & & & $\overline{1}$ & \\
\hline$\overline{\text { Associate }}$ & 71 & & & & & 1 & & 1 & 3 & \\
\hline Assistant & 103 & & & & & & & 1 & 1 & \\
\hline Inst/Lect. & 54 & 1 & 1 & & & & & & & 1 \\
\hline Lab Tech. & 12 & 11 & 11 & & 1 & & & & & 1 \\
\hline High Mgmt. & 3 & & & & & & & & & \\
\hline Middle Low & 61 & 1 & 4 & 12 & & & 1 & & 1 & \\
\hline Technician & 1 & & & & 2 & & & & & \\
\hline Other & 1 & & 1 & & & & 21 & & & \\
\hline Ũnknown & 6 & & 1 & & & & & & & \\
\hline
\end{tabular}

Neither the sex nor the presence of a full-time appointee (vs. a faculty member) alone influence the availability of technological resources and the diversification of disciplines. For example, 36 percent of the female laboratory. leadership are affiliated with laboratories offering technologies in addition to audiotapes and records.

\section{Person in Charge: Education}

Most of the language/learning laboratory leadership possesses either a master's or a doctoral deree. 45.6 percent, while 15.2 percent are engaged in doctoral studies. The male leadership is better educated than the female. Men are concentrated at the master's and doctoral level whereas women at the bachelor's, master's and pre-doctoral level: 
24.6 precent of the men have the master's degree; 15.4 percent are doctoral candidates and 30.8 percent have the doctorate. These three categories total 70.8 percent of their response. Of the women, 28 percent have the bachelor's, 20 percent have the master's and 16 percent are doctoral candidates together comprising 64 percent of their response.

No administrative appointment has the doctorate. Male administrative appointments tend to peak at the master's and female at the bachelor's. Women "Supervisors" do not appear to be as well educated as those employed as "Directors".

\begin{tabular}{|c|c|c|c|c|}
\hline \multirow[b]{2}{*}{ Education } & \multicolumn{3}{|c|}{ Education } & \multirow[b]{2}{*}{$\begin{array}{l}\text { Percentage of } \\
\text { Trtal Responses }\end{array}$} \\
\hline & $\mathbf{M}$ & $\mathbf{F}$ & Total & \\
\hline H.S. Diploma & 2 & 1 & -3 & $3.2 \%$ \\
\hline Associate Degree & 2 & 0 & 2 & $2.2 \%$ \\
\hline Baccalaureat & 0 & 2 & 2 & $2.2 \%$ \\
\hline Some College/Prof. Trng. & 2 & 3 & 5 & $5.4 \%$ \\
\hline Bachelor's & 3 & 7 & 10 & $10.9 \%$ \\
\hline Master's Candidate & 1 & 1 & 2 & $2.2 \%$ \\
\hline Master's & 16 & 5 & 21 & $22.8 \%$ \\
\hline Doctoral Candidate & 7 & 3 & 10 & $10.9 \%$ \\
\hline ABD & 3 & 1 & 4 & $4.3 \%$ \\
\hline Doctorate & 20 & 1 & 21 & $22.8 \%$ \\
\hline Unknown & 9 & 1 & 10 & $10.9 \%$ \\
\hline Not Applicable & & & 2 & $2.2 \%$ \\
\hline
\end{tabular}

The nature of the degree earned by the leadership varies: three report a degree in media; two a degree in library science and six a degree in education (which may have included media and instructional technology). Four possess a degree in computer science and/or electronics. Twenty-five of the leadership earned a degree in language, literature or the humanities.

\section{Person in Charge: Years in Position}

Years in position are reported for 58 of the men and 24 of the women. The average number of years on the job for both sexes is 5.3 years. Women tend to hold the job slightly longer than men, 5.9 years vs. 5.1 years. Men appear to average the greatest number of years on the job at the top of the line, as professors and chairmen. Women do not fare as well. Their greatest number of years are spent as assistant 


\section{University Laboratory}

professors and middle/low level administrators. (See Appendix A, Table A-3, for the Distribution of Years in Position by Title and Rank).

Person in Charge: Salary

Salaries are reported by those in charge as follows: 39 in Group 1; 2 in Group 2; 3 in Group 3; 1 in Group 4. The average male salary reported in April-June 1975 is $\$ 14,888.3$ Their median years on the job (over 26 men) is 5.2 years. The median female salary (over 13 women) is $\$ 13,325.4$ Their median years on the job is 5.5 years.

Person in Charge: Salary

\begin{tabular}{c} 
By Title \\
\hline Table 10 \\
\hline
\end{tabular}

Number of Median

Title Reported Salaries Median Salary Years on Job

\begin{tabular}{lrrrrrrr}
\hline & $\mathrm{M}$ & $\mathrm{F}$ & $\bar{M}$ & $\mathrm{~F}$ & $\mathrm{M}$ & $\mathrm{F}$ \\
\cline { 2 - 7 } Director* & 19 & 6 & $\$ 14,512$ & $\$ 13,058$ & 6.6 & 5.8 \\
Coordinator & 1 & - & 18,400 & $\ldots$ & 1.0 & $\ldots$ \\
Supervisor* & 1 & 3 & 12,200 & 12,600 & 1.0 & 4.4 \\
Administrator/ & & & & & & \\
$\quad$ Manager & 1 & 2 & 13,930 & 11,500 & 1.5 & 5.0 \\
Technician & 1 & - & 13,000 & $\ldots$ & .7 &.. \\
Instructional Aide & - & 1 & $\ldots$ & $825 / \mathrm{mo} . \ldots$ & & 3.0 \\
Assistant-Hourly & 1 & 1 & $3.63 / \mathrm{hr}$. & $3.42 / \mathrm{hr}$. & 5.0 & 1.0 \\
Head & 1 & - & 25,000 & $\ldots$ & 11.5 & $\ldots$ \\
No Title & 2 & - & 14,350 & $\ldots$ & 2.5 & $\ldots$ \\
Title Unknown & 2 & 1 & 15,000 & 10,000 & 4.0 & 6.0
\end{tabular}

* Graduate and Undergraduate Assistants utilizing these titles are considered separately in Table XI.

** The sum reported represents that portion of the salary prorated for laboratory work.

3In NEA Research Memo 1974-1, Summary of Salaries Paid in Higher Education. 1973-74, the 1973-74 median salary for full-time teaching faculty over all ranks and including Department Chairmen is $\$ 14,373$ in 4-year institutions. The 1973-74 median salary for Directors of Audio-Visual Services is $\$ 14,500$.

4The difference between the male and female median salary is consistent with that reported by Darland et.al. in Application of Multivariate Regression to Studies of Salary Differences between Men and Women Faculty, 1974, Darland reports that women terd to be underpaid by about $\$ 1,500$ annually on the average even after all the obvious differences of education, years of experience, et.al. are factored. 
When the data is considered over rank, the range in salary for men appears to be in proportion to the number of years on the job . . except for those in middle/low managerial positions. The female median salary exceeds the male only when the number of years on the job are far greater.

$\begin{gathered}\text { Person in Charge: Salary } \\ \text { By Rank }\end{gathered}$
Number of

Rank

Professor

Associate Professor

2

F

Assistant Professor
Instructor/Lecturer
College Lab.

Technician

High Managerial

Middle/Low

Managerial

Technician

Assistant-Hourly

Assistant-Undergrad/ 1

Graduate

Rank Unknown 1

$\begin{array}{cccccc}1 . & 2 & 12,200 & 15,600 & 1.0 & 7.0 \\ 3 & - & 19,517 & \ldots & 5.6 & \cdots\end{array}$

* Only this prorated portion of salary is reported.

Nine of those who teach in addition to their laboratory responsibility report their salary. The median over eight is $\$ 13,888$. The ninth, as described above, prorates the lab portion of his salary to be worth $\$ 2,200$. Where salaries are given for those responsible for labs with more than 100 booths, five of the labs are under the leadership of men earning $\$ 18,000-25,000$; four under men earning $\$ 12,200-15,500$; two under women earning $\$ 11,000-13,000$ per year.

\section{Person Reported To: Title}

The ninety persons in charge of the lab are responsible to a total of ninety-four others. The majority of the ninety-four, 62.8 percent, are Department Chairmen. The others are Vice-Presidents, Deans, Directors of mediated Centers and Chief Librarians. This leadership 


\section{University Laboratory}

is primarily male, 77.7 percent compared to 12.7 percent female; 9.6 percent is not identified by sex. Of the men, 63 percent are Chairmen, especially of foreign or modern language departments; 11 percent are Directors of media centers; 23 percent are Vice-Presidents and Deans (including Associate and Assistant). Of the women, 75 percent are Chairpersons; 25 percent are Deans (including Associate). Two of the three female Deans are employed by women's colleges. See Appendix A Table A4, for the listing of the person reported to by title).

\section{Person Reported To: Rank}

At this step, most appointments are on the professorial line, 75.5 percent. Few are administrative, 3.2 percent (in contrast to the 34.5 percent of laboratory leadership on administrative lines). Only those Deans, Associate Deans and Vice-Presidents whose academic rank is not specifically designated on the questionnaire, are included as such in Table 12 below.

Person Reported To: Rank

Table 12

\begin{tabular}{lrrrrr} 
& & & & $\begin{array}{c}\text { Percentage of } \\
\text { Rank }\end{array}$ \\
\cline { 2 - 5 } M & F & $?$ & Total & Total Responses \\
\hline Professor & 39 & 7 & 2 & 48 & $51.1 \%$ \\
Associate Prof. & 13 & 2 & - & 15 & $15.9 \%$ \\
Assistant Prof. & 6 & 1 & 1 & 8 & $8.5 \%$ \\
Chief Librarian & 2 & - & - & 2 & $2.1 \%$ \\
Officer/Admin. & 3 & - & - & 3 & $3.2 \%$ \\
Associate Dean & - & 1 & - & 1 & $1.1 \%$ \\
Dean & 7 & - & 4 & 11 & $11.7 \%$ \\
Vice-President & 2 & - & - & 2 & $2.1 \%$ \\
Rank Unknown & 1 & 1 & 2 & 4 & $4.3 \%$
\end{tabular}

Person Reported to: Education

The overwhelming majority of this leadership possesses the doctorate, 77.7 percent. All full professors, deans and vice-presidents for whom a degree is reported hold a doctorate. All female leadership at this level possesses the degree as well. The five identified master's degrees are held by males: one assistant and two associate professors; one administrative appointee; one of unknown rank.

The nature of the degree varies: two in media, three in education; one in business administration; twenty-eight in language, literature (including English); six in areas such as Biology, Chemistry, Political Science, etc. 
Pcrson Reported To: Years in Position

Years in position are reported for 65 men and 9 women. Women appear to be newer to their professorial appointments than to their laboratory appointments for their median years at this level is 3.1 compared with 5.9 in the lab. The male median years at this level is 5.3. (See Appendix A, Table A-5 for a listing by rank and title).

Distribution of Facility over Person Reported to.

Chairpersons are overwhelmingly responsible for language laboratories: 54 of the total 59 assume this leadership with their title. Of the fifty language labs that fall under their domain, thirty-seven offer only the foreign languages and English as a Second Language. Of the eighteen Deans, fourteen are responsible for language laboratories as are four of the nine Directors. Language Centers, Learning Labs, et.al. (Groups 2, 3, 4), in proportion to their number, are under Directors, Chief Librarians and Deans rather than Chairpersons.

The diversification of available techrology does not appear to be influenced by the person reported to, but there does appear to be a relationship between the size of the lab and the person to whom it reports. Ten of the eighteen labs reporting to a Dean are over 95 booths while only nine of the fifty reporting to a Chairperson are over 95 booths. The remaining are from 30-38 booths, 40-53 booths and 60-70 booths. In Table 13, the columns represent the number of university administrators by the facility reporting to them, i.e. one Vice-President is responsible for ore language lab and one for one Listening Center (Other Names, Group 4).

Distribution of Facility over Person Reported to

\begin{tabular}{|c|c|c|c|c|}
\hline & $\mathrm{Table}_{1} 13$ & 2 & 3 & 4 \\
\hline Person Reported to: & $\begin{array}{c}\text { Language } \\
\text { Labs }\end{array}$ & $\begin{array}{l}\text { Language } \\
\text { Centers }\end{array}$ & $\begin{array}{l}\text { Learning } \\
\text { Labs }\end{array}$ & $\begin{array}{l}\text { Other } \\
\text { Names }\end{array}$ \\
\hline Vice-President & 1 & - & - & 1 \\
\hline Dean & $14^{*}$ & 2 & 2 & $\cdot$ \\
\hline Associate Dean & 2 & 1 & - & - \\
\hline Assistant Dean & 1 & - & - & - \\
\hline Director & 4 & - & 3 & 2 \\
\hline Chief Librarian & - & - & 1 & 1 \\
\hline Chairperson & $54^{* *}$ & 1 & 2 & 1 \\
\hline
\end{tabular}

(See Appendix A, Table A.6, for the distribution of Person Reported to by title over Laboratory Leadership by rank). 


\section{University Laboratory}

Others Employed in the Facility

This section examines the organization established to operate. Three major personnel configuration are discerned: those based on the services of 1) students only (including graduate, college, laboratory and teaching assistants, 5 and tutors);

2) one or more technicians (usually full-time), the above student personnel and any combination of secretaries, clerks, program coordinators and librarians;

3) one or more managers or assistant directors and any combination of the above student, technical and clerical personnel. It must be noted that forty-six of the eighty-nine labs responding to the questionnaire make no reference to the technical personnel who repair the equipment (thirty-six of the forty-six report to chairpersons, one to a chief librarian, three to directors and six to deans). It can only be assumed that University-wide audio-visual/technical personnel or contracts available through vendors provide essential maintenance.

\section{Student Aides...}

Of the labs omitting any reference to repairs, 78.3 percent are in this category. Student Assistants, in addition to the person in charge, are the only help in thirty-two of the laboratories polled. Six labs operate only with college, laboratory, graduate or teaching assistants or a clerk; three utilize a combination of the above personnel. The forty-one labs in this grouping comprise 43.8 percent of the total response. sCollege, Laboratory, Graduate, Teaching Assistants and Tutors are defined as more specialized help on the hourly scale (better paid than student assistants, but not as well as technicians).

Almost half of the labs in Group 1, language labs, operate with hourly or part-time assistance only as do 66.7 percent of the other named labs in Group 4.

In this configuration of personnel, 28.6 percent of the leadership did not clearly define its status, i.e. teaching faculty or full-time. (However, this clarification was not specified on the questionnaire). Fulltime appointments were reported by 36.6 percent of the leadership and teaching responsibilities by 28.6 percent. Teaching faculty appear to be responsible for labs employing student aides rather than for labs employing graduate assistants, et.al. Only once is a faculty member responsible for a lab staffed with college assistants et.al.

One technology ... tapes . . is offered in 62.5 percent of the labs operating with student or hourly help; video is provided by 18.7 percent of them. The use of college assistants et.al. does not imply additional technologies (or student positions). However, video does appear to be installed where the person in charge is a full-time appointment. 
Technicians and ...

Laboratories staffed with one of more technicians (usually full-time) and a combination of student aides, graduate or teaching assistants, secretaries, clerks, program coordinators, librarians, et.al. represent 27 percent of the total response. They are language labs or centers (Groups 1 and 2) ranging from 26 to 300 student positions. In this configuration, 48 percent of the leadership did not define its status. Less than half, 40 percent, of the labs are known to be under full-time appointments and 12 percent under teaching faculty. The presence of a technician does not indicate additional resources: 54.5 percent of the labs in this category offer tape recordings only; 33.3 percent provide video facilities.

\section{Managers and ...}

The last primary configuration of personnel operates under the direction of one or more associate or assistant directors, or managers or supervisors, and the above student, technical and clerical personnel in addition to the person in charge. Some 20.2 percent of the labs follow this pattern; 36.8 percent of these labs make no reference to equipment repairs while 52.7 percent of them employ technicians. Most of the labs organized around a full-time manager are language labs, 68.4 percent; 21.2 percent are learning labs. Of all learning labs, 50 percent follow this personnel configuration. The commitment to the lab by the person in charge is not made clear in 31.6 percent of the responses in this grouping. A full-time person is in charge of $\mathbf{4 2 . 1}$ percent of the labs following this configuration while a faculty member is responsible for 26.3 percent of them.

When a full-time manager is employed, video is more frequently utilized: 47.4 percent of the labs in this category have the medium installed. Visuals are used in 47.4 percent of them and tapes alone in 36.8 percent of them.

\section{Other Configurations}

Two final personnel configurations considered separately include a computer programmer and a graphic artist. These are two positions unique within the labs surveyed. (Another lab cites a position of media specialist filed by two graduate assistants and therefore, not included here). Both labs in this configuration are small, 16 and 20 booths. They are a learning and autotutorial lab, Groups 3 and 4, and provide both video and visuals as part of the available technologies. (See Appendix A, Table A-7, for the distribution of Personnel Configurations by the Person in Charge, the Facility and the Technologies Available). 


\section{University Laboratory}

Numbers of People Employed.

The number of student aides or assistants employed in the labs surveyed range from zero to twenty-two.

\begin{tabular}{|c|c|}
\hline \multicolumn{2}{|c|}{$\begin{array}{c}\text { Student Aides } \\
\text { Table } 14\end{array}$} \\
\hline $\begin{array}{l}\text { Number of Student Aides } \\
\text { None }\end{array}$ & $\begin{array}{l}\text { Number of Labs } \\
15\end{array}$ \\
\hline $2-4$ & 19 \\
\hline 5- 6 & 5 \\
\hline $7-11$ & 14 \\
\hline $12-15$ & 11 \\
\hline 19-22 & 4 \\
\hline Students Employe & 19 \\
\hline Not Clear & 2 \\
\hline
\end{tabular}

When the students are listed by sex, there are 53 male and 59 female aides. Other staff members listed by sex and number include:

\section{Staff Members}

\begin{tabular}{|c|c|c|c|}
\hline \multirow[b]{2}{*}{ Staff Member } & \multicolumn{3}{|c|}{ Numbers Employed } \\
\hline & & $\mathbf{M}$ & $F$ \\
\hline Manager & & 12.5 & $\overline{11}$ \\
\hline Technician & & 44 & - \\
\hline Recording Technicia & & 4.25 & 2 \\
\hline Secretary & & 1 & 20 \\
\hline Clerk & & - & 5 \\
\hline Librarian & & - & 4 \\
\hline Program Coordinato & & - & 4 \\
\hline Programming Assist & & - & 1 \\
\hline Media Operator & & - & 1 \\
\hline Computer Programn & & 1 & - \\
\hline Computer Card Con & ipiler & - & 1 \\
\hline Tutor* & & 2 & - \\
\hline Teaching Assistant & & * & * \\
\hline Graduate Assistant & & 1.5 & $\mathbf{3}$ \\
\hline College/Laboratory & Asst. 1 & & 11 \\
\hline
\end{tabular}

*Exact numbers were not specified by several labs employing tutors and teaching assistants. 


\section{Observations and Conclusions}

1. This survey represents an attempt to provide some documentation on the types of language/learning laboratories established across the United States. Additional documentation is needed as well. The nature and number of technological centers and services available on the campuses surveyed have not been determined. It is only known that the sampling of language labs far outweigh that of learning labs in this particular study. It is not known whether this is indicative of the reality. It is also important to determine the extent to which the media is integrated into curriculum practices and the criteria by which the technology is selected. Clarifications are essential if effective laboratory practices are to be defined and implemented.

2. The organizational structure of the language/learning labs has long been neglected as a viable factor in their effective functioning. For the most part, it does not appear that the leadership in this survey possesses sufficient status and/or authority to effect efficient implementation of the media into the higher education curriculum. Many who teach are not rewarded for their laboratory commitment while others lack the rank or education for their efforts to have any impact. The Carnegie Commission recommended that responsibility for the utilization of instructional technology be placed at "the highest possible level of academic administration". 6 The implementation of this recommendation in the laboratory might minimize the variation in laboratory activities, commitments and reporting practices.

6Carnegie Commission on Higher Education, The Fourth Revolution. Instructional Technology in Higher Education, 1972. p. 51.

3. Discrimination against women exists in the language/learning laboratory across all ranks and titles, regardless of whether by choice or circumstances, as elsewhere in higher education. Women in laboratory positions are paid less than their male counterparts. The myth of technical (i.e. male) competency, traditionally associated with an effective laboratory operation, dissipates in this survey where almost half of the male leadership omitted any reference to this competency within their own laboratories.

\section{BIBLIOGRAPHY}

Carnegie Commission on Higher Education. The Fourth Revolution. Instructional Technology in Higher Education. New York, McGraw Hill, 1972.

Centra, John A. "Women with Doctorates." Change, 7:1, February 1975 , pp. 49, 61. 


\section{University Laboratory}

Darland, M.G., S. M. Dawkins et. al, Application of Multivariate Regression to Studies of Salary Differences between Men and Women Faculty Berkeley, Calif. Univ. of California. 1974, 13 pp. ED 089 638.

Davies, Norman and J R. Allen. System. A Newsletter for'Educational Technology and Language Learning Systems. Sweden, Linkoping University, 2:1, January 1974, 74 pp. ED 093164.

Deti, Daniel V. "The Human Factor and Efficient Utilization of the Language Laboratory." NALLD Journal, 7:2, Winter 1973, pp. 23-39.

Dozier, Jane. Exploratory Study on Audio-Visual Media at Stanford University. Palo Alto, Calif., Stanford Univ., January 1974, 31 pp. ED 089775.

Graybeal, William Summary of Salaries Paid in Higher Education. 1973-1974. National Education Association Research Memo 1974-1. Washington D.C., November 1974, 12 pp. ED 098-843

Kazlow, Carole, and J. Giacquinta. Faculty Receptivity to Organizational Change. Paper presented at the annual meeting of the American Educational Research Association, Chicago. April 1974, 31 pp. ED 090847.

National Center for Educational Statistics. "Preliminary Estimates of 1972-73 Full-Time Instructional Faculty in Institutions if Higher Education." Bulletin. Advance Statistics for Management. HEW/ OE, Washington D.C., 14, March 1, 1973, 4 pp. ED 087289.

\section{Appendix A}

Appendix A contains the following information:

1) Nature of the Facility

Distributions of Disciplines and Technologies over Facility (Tables A-1 and A-2)

2) Person in Charge. Years in Position by Title and Rank (Table A-3)

3) Person Reported to.

Titles (Table A-4)

Years in Position by Title and Rank (Table A-5)

Distribution of Person Reported to over Lab Leadership by Title and Rank (Table A-6)

4) Others Employed in Facility

Personnel Configurations by Type of facility, Pcrson in Charge and Techrologies (Table A-7) 